\title{
Production of Enterobacterial Common Antigen as an Aid to Classification of Newly Identified Species of the Families Enterobacteriaceae and Vibrionaceae
}

\author{
SAMI RAMIA, ${ }^{1}$ ERWIN NETER, ${ }^{1,2}$ AND DON J. BRENNER ${ }^{3}$ \\ Division of Clinical Microbiology and Immunology, Erie County Laboratory, Erie County Medical Center, \\ Buffalo, New York 14215' ; Departments of Microbiology and Pediatrics, State University of New York at \\ Buffalo, and Laboratory of Bacteriology, Children's Hospital of Buffalo, Buffalo, New York 142222 ; and \\ Enteric Bacteriology and Epidemiology Branch, Bacterial Diseases Division, Center for Infectious Diseases, \\ Centers for Disease Control, Atlanta, Georgia $30333^{3}$
}

A study on the production of enterobacterial common antigen by recently described or as-yet-undescribed species belonging to the families Enterobacteriaceae and Vibrionaceae was carried out by hemagglutination and hemagglutination inhibition tests with rabbit antisera specific for this antigen. All 28 strains known or presumed to belong to Enterobacteriaceae produced this antigen, and none of the seven strains belonging to Vibrionaceae did so. The results obtained with Tatumella ptyseos and Xenorhabdus species are particularly noteworthy, since they represent species which are atypical for Enterobacteriaceae. It is suggested that the determination of the production of enterobacterial common antigen is a significant aid to classification, particularly when the assignation of a new genus or species to Enterobacteriaceae or to another family presents a problem.

Enterobacterial common antigen (ECA), which is common to members of the family Enterobacteriaceae, was first described by Kunin et al. $(16,17)$. As reviewed by Mäkelä and Mayer (22), this antigen is produced by numerous members of the family Enterobacteriaceae but not by species belonging to other families. A few strains belonging to the family Enterobacteriaceae do not produce the antigen because of a documented or presumed mutation. The only species of Enterobacteriaceae which apparently does not produce ECA is Erwinia chrysanthemi (20). As far as species belonging to other families are concerned, a possible exception to the rule is strains previously identified as Aeromonas shigelloides and presently listed as Plesiomonas shigelloides which do produce ECA $(20,29)$. In view of the possible usefulness of ECA production in the classification of organisms at the family level, recently described and undescribed species belonging to the families Enterobacteriaceae and Vibrionaceae were investigated.

In this study, strains of 35 newly described or as-yet-unnamed species of Enterobacteriaceae and Vibrionaceae were tested for the presence of ECA.

\section{MATERIALS AND METHODS}

All strains were from the culture collection of the Enteric Diseases Reference Laboratories in the Enteric Bacteriology Section, Enteric Bacteriology and
Epidemiology Branch, Centers for Disease Control. Type strains or deoxyribonucleic acid (DNA) reference strains were used for all species. The sources of the strains are given in Table 1 . Strains were coded at Atlanta, Ga., and tested blind in Buffalo, N.Y. The codes given to these strains were not in the order shown in Table 1. References to the recently described species are given in Table 1. Enteric groups refer to potential new species now under study in the Enteric Diseases Reference Laboratories. DNA groups refer to new species that have not yet been published or named.

All strains were seeded onto chocolate agar and incubated at either 20 or $36^{\circ} \mathrm{C}$, depending upon the temperature optima of individual species. Since all strains produced heavy confluent growth on chocolate agar, suspensions were made from this culture medium incorporating the growth of three agar plates each in $6 \mathrm{ml}$ of phosphate hemagglutination buffer (Difco). Based on serial dilution, the number of organisms in each suspension was approximately $10^{12}$ cells per $\mathrm{ml}$. The suspensions were heated in boiling water for $1 \mathrm{~h}$ and centrifuged at 23,500 $\times g$ for $10 \mathrm{~min}$. The supernatants were used as antigens. For control purposes, supernatants of an ECA-positive Escherichia coli strain and an ECA-negative Pseudomonas aeruginosa strain were used, and these preparations yielded the expected results.

The hemagglutination test was carried out as described previously (23). Briefly, to the sediment of three-times-washed human erythrocytes (blood group $\mathrm{O}$; Rh-negative; $2.5 \%$ suspension) was added antigen in a dilution of $1: 10$. The suspension was incubated at $37^{\circ} \mathrm{C}$ and washed three times to remove excess antigen. The antigenically modified erythrocytes $(0.2 \mathrm{ml})$ 
TABLE 1. Production of ECA in 35 recently described species or groups of Enterobacteriaceae and Vibrionaceae

\begin{tabular}{|c|c|c|c|}
\hline Organism & Reference & Source $^{a}$ & $\begin{array}{c}\text { ECA } \\
\text { present }\end{array}$ \\
\hline $\begin{array}{l}\text { Cedecea davisae 3278-77 } \\
\text { (CIP 80.34, ATCC 33431) }\end{array}$ & 7 & CDC & + \\
\hline $\begin{array}{l}\text { Cedecea lapagei 485-76 } \\
\text { (CIP 80.35, ATCC 33432) }\end{array}$ & 7 & $\mathrm{CDC}$ & + \\
\hline $\begin{array}{l}\text { Edwardsiella hoshinae } 2169-80 \\
\text { (CIP 78.56, ATCC 33379) }\end{array}$ & 9 & P. A. D. Grimont & + \\
\hline $\begin{array}{l}\text { Edwardsiella ictaluri 1976-78 } \\
\text { (GA-77-52, ATCC 33202) }\end{array}$ & 11 & J. P. Hawke & + \\
\hline $\begin{array}{l}\text { Enterobacter amnigenus } 1325-79 \\
\text { (CUETM 78-118, ATCC 33072) }\end{array}$ & 15 & H. Leclerc & + \\
\hline $\begin{array}{l}\text { Enterobacter gergoviae 604-77 } \\
\text { (CIP 76.01, ATCC 33028) }\end{array}$ & 1 & C. Richard & + \\
\hline $\begin{array}{l}\text { Enterobacter intermedium } 2992-79 \\
\text { (Leclerc } 77-148 \text { ) }\end{array}$ & 14 & H. Leclerc & + \\
\hline $\begin{array}{l}\text { Escherichia blattae } 9005-74 \\
\text { Hafnia DNA group } 23226-74\end{array}$ & $\begin{array}{r}2 \\
26\end{array}$ & $\begin{array}{l}\text { N. R. H. Burgess } \\
\text { CDC }\end{array}$ & $\begin{array}{l}+ \\
+\end{array}$ \\
\hline $\begin{array}{l}\text { Kluyvera ascorbata 648-74 } \\
\text { (ATCC 33433) }\end{array}$ & 5 & $\mathrm{CDC}$ & + \\
\hline $\begin{array}{l}\text { Kluyvera cryocrescens 2065-78 } \\
\text { (ATCC 33435) }\end{array}$ & 5 & $\mathrm{CDC}$ & + \\
\hline $\begin{array}{l}\text { Obesumbacterium proteus } 1496-74 \\
\text { (Priest 502, NCIB 8771) }\end{array}$ & 25 & F. G. Priest & + \\
\hline $\begin{array}{l}\text { Proteus DNA group 1808-73 } \\
\text { Providencia DNA group 132-68 }\end{array}$ & & $\begin{array}{l}\mathrm{CDC} \\
\mathrm{CDC}\end{array}$ & + \\
\hline $\begin{array}{l}\text { Serratia ficaria } 1165-79 \\
\text { (CIP 79.23, ICPB } 4050, \text { ATCC 33105) }\end{array}$ & 10 & P. A. D. Grimont & + \\
\hline $\begin{array}{l}\text { Serratia fonticola 2988-79 } \\
\quad \text { (ATCC 29844) }\end{array}$ & 6 & H. Leclerc & + \\
\hline $\begin{array}{l}\text { Serratia odorifera 1979-77 } \\
\text { (Grimont 1073, ICPB 3995) }\end{array}$ & 8 & P. A. D. Grimont & + \\
\hline $\begin{array}{l}\text { Tatumella ptyseos H36 } \\
\text { (9591-78, D6168, ATCC 33301) }\end{array}$ & 13 & $\mathrm{CDC}$ & + \\
\hline $\begin{array}{l}\text { Xenorhabdus luminescens } 9016-80 \\
\text { (Thomas Hb, ATCC 29999) }\end{array}$ & 28 & G. M. Thomas & + \\
\hline $\begin{array}{l}\text { Xenorhabdus nematophilus 1184-80 } \\
\text { (ATCC 19061) }\end{array}$ & 28 & G. M. Thomas & + \\
\hline $\begin{array}{l}\text { Xenorhabdus DNA group } 3 \text { 1195-80 } \\
\text { (Thomas NC-19, ATCC 29304) }\end{array}$ & 28 & G. M. Thomas & + \\
\hline $\begin{array}{l}\text { Xenorhabdus DNA group } 4 \text { 9014-80 } \\
\text { (Thomas DN) }\end{array}$ & 28 & G. M. Thomas & + \\
\hline Enteric group $1875-72$ & & $\mathrm{CDC}$ & + \\
\hline Enteric group 10 1350-81 & & CDC & + \\
\hline Enteric group 11 980-72 & & $\mathrm{CDC}$ & + \\
\hline Enteric group 19 1042-80 & & $\mathrm{CDC}$ & + \\
\hline Enteric group 45 329-73 & & $\mathrm{CDC}$ & + \\
\hline Enteric group 46 2896-78 & & $\mathrm{CDC}$ & + \\
\hline $\begin{array}{l}\text { Aeromonas sobria 9538-76 } \\
\text { (Popoff 278, CIP 7433) }\end{array}$ & 24 & M. Popoff & - \\
\hline $\begin{array}{l}\text { Vibrio damsela 2588-80 } \\
\text { (ATCC 33539) }\end{array}$ & 21 & M. Love & - \\
\hline $\begin{array}{l}\text { Vibrio fluvialis } 9555-78 \\
\text { (VL 5125, NCTC 11327) }\end{array}$ & 19 & J. V. Lee & - \\
\hline $\begin{array}{l}\text { "Vibrio hollisae" } 75-80 \\
\text { (ATCC 33564) }\end{array}$ & 12 & $\mathrm{CDC}$ & - \\
\hline $\begin{array}{l}\text { Vibrio metschnikovii 1316-78 } \\
\text { (NCTC 8443) }\end{array}$ & 18 & NCTC & - \\
\hline $\begin{array}{l}\text { Vibrio mimicus 1721-77 } \\
\text { (ATCC 33653) }\end{array}$ & 3 & CDC & - \\
\hline $\begin{array}{l}\text { Vibrio vulnificus } 9107-79 \\
\quad \text { (ATCC 27562) }\end{array}$ & 4 & ATCC & - \\
\hline
\end{tabular}

a CDC, Centers for Disease Control, Atlanta, Ga.; ATCC, American Type Culture Collection, Rockville, Md.; NCTC, National Collection of Type Cultures, London, England.

${ }^{b}$ Not validly published to date. 
were added to equal volumes of ECA antiserum in twofold serial dilutions. The mixtures were incubated for $30 \mathrm{~min}$ in a $37^{\circ} \mathrm{C}$ water bath, and hemagglutination was read grossly after centrifugation at $1,300 \times g$ for 2 min.

The hemagglutination inhibition test was performed as follows. To ECA antiserum in twofold serial dilutions $(0.2 \mathrm{ml})$ were added equal amounts of undiluted antigen. The mixtures were incubated for $30 \mathrm{~min}$ in a $37^{\circ} \mathrm{C}$ water bath. Erythrocytes modified with ECA obtained from $E$. coli were added, and the hemagglutination test was completed as described above.

ECA antiserum was obtained by immunization of rabbits with either $E$. coli 014 or the ethanol-soluble ECA preparation from Salmonella typhimurium, as described previously (27).

The hemolysis test was done as described above except that sheep erythrocytes instead of human erythrocytes were used, and guinea pig complement in a dilution of 1:10 was added. Hemolysis was read grossly after incubation for $1 \mathrm{~h}$ at $37^{\circ} \mathrm{C}$.

\section{RESULTS}

Table 1 shows the results of independently executed hemagglutination tests on organisms belonging to 35 bacterial species. Positive and negative control preparations yielded appropriate results. All species known or presumed to be members of the Enterobacteriaceae were positive for the production of ECA, and all species known or presumed to be members of the $V i$ brionaceae (genera Vibrio and Aeromonas) were negative. Hemagglutination occurred with all positive strains with $E$. coli 014 and ECA antisera in dilutions of $1: 800$ to $1: 1,600$; all other strains yielded negative results even when the antisera were used in a dilution of 1:50. Additional experiments using the hemolysis test yielded concordant results. To make certain that negative hemagglutination and hemolysis tests were due to the absence of ECA and not to its failure to become attached to erythrocytes, hemagglutination inhibition tests were carried out. The results clearly indicated that ECA was not produced by any of the negative strains. These observations suggest that production of an antigen essentially characteristic of a family may be one of many useful indicators for classification.

\section{DISCUSSION}

Seven of the species tested belonged to either Vibrio or Aeromonas. As expected, these organisms were all negative for ECA. The 28 species known or presumed to belong to the Enterobacteriaceae all produced ECA. The positive results were particularly gratifying for Tatumella ptyseos and Xenorhabdus species, because these species are quite atypical for Enterobacteriaceae. T. ptyseos is a polar flagellate (13), Xenorhabdus nematophilus is catalase negative, and Xenorhabdus species do not reduce nitrates (28).
These and previously obtained results $(16,17$, $20,22,23,27,29)$ establish ECA as a powerful taxonomic tool with which to separate the $E n$ terobacteriaceae from other families. The only exceptions (other than a rare negative strain of Enterobacteriaceae) are the negative results obtained with all six tested strains of Erwinia chrysanthemi (20) and the positive results obtained with six Plesiomonas shigelloides strains $(20,29)$. It is our opinion that ECA production is a valuable addition to the description of the family Enterobacteriaceae and should be required in those instances where the assignation of a new genus to Enterobacteriaceae or to another family creates a problem.

\section{ACKNOWLEDGMENTS}

We are grateful to Mary Alyce Asbury, Geraldine P. Huntley-Carter, Betty R. Davis, Frances W. Hickman, and Alma C. McWhorter for providing the strains and to Frances W. Hickman for coding the strains and decoding the results. Thanks are expressed also to Helga von Langendorff for assistance with the antigen tests.

This research was supported in part by Public Health Service grant AI 00658 from the National Institute of Allergy and Infectious Diseases (to E.N.).

\section{REPRINT REQUESTS}

Address reprint requests to: Dr. Erwin Neter, Department of Microbiology, State University of New York at Buffalo, and Children's Hospital, Buffalo, NY 14222.

\section{LITERATURE CITED}

1. Brenner, D. J., C. Richard, A. G. Stelgerwalt, M. A. Asbury, and M. Mandel. 1980. Enterobacter gergoviae sp. nov.: a new species of Enterobacteriaceae found in clinical specimens and the environment. Int. J. Syst. Bacteriol. 30:1-6.

2. Burgess, N. R. H., S. N. McDermott, and J. Whiting. 1973. Aerobic bacteria occurring in the hind-gut of the cockroach, Blatta orientalis. J. Hyg. 71:1-7.

3. Davis, B. R., G. R. Fanning, J. M. Madden, A. G. Stelgerwalt, H. B. Bradford, Jr., H. L. Smith, Jr., and D. J. Brenner. 1981. Characterization of biochemically atypical Vibrio cholerae strains and designation of a new pathogenic species, Vibrio mimicus. J. Clin. Microbiol. 14:631639.

4. Farmer, J. J., III. 1980. Revival of the name Vibrio vulnificus. Int. J. Syst. Bacteriol. 30:656.

5. Farmer, J. J., II, G. R. Fanning, G. P. Huntley-Carter, B. Holmes, F. W. Hickman, C. Richard, and D. J. Brenner. 1981. Kluyvera, a new (redefined) genus in the family Enterobacteriaceae: identification of Kluyvera ascorbata sp. nov. and Kluyvera cryocrescens sp. nov. in clinical specimens. J. Clin. Microbiol. 13:919-933.

6. Gavini, F., C. Ferragut, D. Izard, P. A. Trinel, H. Leclerc, B. Lefebvre, and D. A. A. Mossel. 1979. Serratia fonticola, a new species from water. Int. J. Syst. Bacteriol. 29:92-101.

7. Grimont, P. A. D., F. Grimont, J. J. Farmer II, and M. A. Asbury. 1981. Cedecea davisae gen. nov., sp. nov. and Cedecea lapagei sp. nov., new Enterobacteriaceae from clinical specimens. Int. J. Syst. Bacteriol. 31:317326.

8. Grimont, P. A. D., F. Grimont, C. Richard, B. R. Davis, A. G. Steigerwalt, and D. J. Brenner. 1978. Deoxyribonucleic acid relatedness between Serratia plymuthica and other Serratia species, with a description of Serratia odorifera sp. nov. (type strain: ICPB 3995). Int. J. Syst. Bacteriol. 28:453-463. 
9. Grimont, P. A. D., F. Grimont, C. Richard, and R. Sakazakii. 1980. Edwardsiella hoshinae, a new species of Enterobacteriaceae. Curr. Microbiol. 4:347-351.

10. Grimont, P. A. D., F. Grimont, and M. P. Starr. 1979 Serratia ficaria sp. nov., a bacterial species associated with Smyrna figs and the fig wasp Blastophaga psenes. Curr, Microbiol. 2:277-282.

11. Hawke, J. P., A. C. McWhorter, A. G. Steigerwalt, and D. J. Brenner. 1982. Edwardsiella ictaluri sp. nov., the causative agent of enteric septicemia of catfish. Int. J. Syst. Bacteriol. 31:396-400.

12. Hickman, F. W., J. J. Farmer III, D. G. Hollis, G. R. Fanning, A. G. Steigerwalt, R. E. Weaver, and D. J. Brenner. 1982. Identification of Vibrio hollisae sp. nov. from patients with diarrhea. J. Clin. Microbiol. 15:395-401.

13. Hollis, D. G., F. W. Hickman, G. R. Fanning, J. J. Farmer III, R. E. Weaver, and D. J. Brenner. 1981. Tatumella ptyseos gen. nov., sp. nov., a member of Enterobacteriaceae found in clinical specimens. J. Clin. Microbiol. 14:79-88.

14. Izard, D., F. Gavini, and H. Leclerc. 1979. Polynucleotide sequence relatedness and genome size among Enterobacter intermedium sp. nov. and the species Enterobacter cloacae and Klebsiella pneumoniae. Zentralbl. Bakteriol. Parasitenkd. Infektionskr. Hyg. Abt. 1 Orig. Reihe C 1:51-60.

15. Izard, D., F. Gavini, and H. Leclerc. 1981. Deoxyribonucleic acid relatedness between Enterobacter cloacae and Enterobacter amnigenus sp. nov. Int. J. Syst. Bacteriol. 31:35-42.

16. Kunin, C. M. 1963. Separation, characterization, and biological significance of a common antigen in Enterobacteriaceae. J. Exp. Med. 118:565-586.

17. Kunin, C. M., M. V. Beard, and N. E. Halmagyl. 1962. Evidence for a common hapten associated with endotoxin fractions of $E$. coli and other Enterobacteriaceae. Proc. Soc. Exp. Biol. Med. 111:160-166.

18. Lee, J. V., T. J. Donovan, and A. L. Furniss. 1978. Characterization, taxonomy, and amended description of Vibrio metschnikovii. Int. J. Syst. Bacteriol. 28:99-111.
19. Lee, J. V., P. Shread, A. L. Furniss, and T. N. Bryant. 1981. Taxonomy and description of Vibrio fluvialis sp. nov. (synonym group F vibrios, group EF6). J. Appl. Bacteriol. 50:73-95.

20. Le Minor, L., A.-M. Chalon, and M. Véron. 1972. Recherche sur la présence de l'antigène commun des Enterobacteriaceae (antigène Kunin) chez les Yersinia, Levinea, Aeromonas et Vibrio. Ann. Inst. Pasteur, Paris 123:761774.

21. Love, M., D. Teebken-Fisher, J. E. Hose, J. J. Farmer III, F. W. Hickman, and G. R. Fanning. 1981. Vibrio damsela, a marine bacterium, causes skin ulcers on the damselfish Chromis punctipinnis. Science 214:1139-1140.

22. Makelă, P. H., and H. Mayer. 1976. Enterobacterial common antigen. Bacteriol. Rev. 40:591-632.

23. Neter, E., O. Westphal, O. Laderitz, and E. A. Gorzynski. 1956. The bacterial hemagglutination test for the demonstration of antibodies to Enterobacteriaceae. Ann. N. Y. Acad. Sci. 66:141-156.

24. Popofi, M., and M. Veron. 1976. A taxonomic study of the Aeromonas hydrophila-Aeromonas punctata group. J. Gen. Microbiol. 94:11-22.

25. Priest, F. G., H. J. Somerville, J. A. Cole, and J. S. Hough. 1973. The taxonomic position of Obesumbacterium proteus, a common brewery contaminant. J. Gen. Microbiol. 75:295-307.

26. Steigerwalt, A. G., G. R. Fanning, M. A. Fife-Asbury, and D. J. Brenner. 1975. DNA relatedness among species of Enterobacter and Serratia. Can. J. Microbiol. 22:121-137.

27. Suzuki, T., E. A. Gorznyskd, and E. Neter. 1964. Separation by ethanol of common and somatic antigens of Enterobacteriaceae. J. Bacteriol. 88:1240-1243.

28. Thomas, G. M., and G. O. Poinar, Jr. 1979. Xenorhabdus gen. nov., a genus of entomopathogenic, nematophilic bacteria of the family Enterobacteriaceae. Int. J. Syst. Bacteriol. 29:352-360.

29. Whang, H. Y., M. E. Heller, and E. Neter. 1972. Production by Aeromonas of common enterobacterial antigen and its possible taxonomic significance. J. Bacteriol. 110:161-164. 